\title{
Physiological and agronomical responses of Syrah grapevine under protected cultivation
}

\author{
Claudia Rita de Souza ( $\left.{ }^{1 *}\right)$; Renata Vieira da Mota ('); Frederico Alcântara Novelli Dias (²); Evaldo \\ Tadeu de Melo ( ${ }^{2}$ ); Rodrigo Meirelles de Azevedo Pimentel ('); Laís Cristina de Souza ( ${ }^{3}$ ); \\ Murillo de Albuquerque Regina (')
}

\author{
(') Empresa de Pesquisa Agropecuária de Minas Gerais (EPAMIG), Núcleo Tecnológico Epamig Uva e Vinho, \\ Avenida Santa Cruz, 500, 37780-000 Caldas (MG), Brasil. \\ (2) Universidade Federal de Lavras (UFLA), Departamento de Agricultura, Caixa Postal 3037, 37200-000 Lavras (MG), Brasil. \\ (3) Universidade Federal de Alfenas (UNIFAL), Rodovia José Aurélio Vilela, 11999, 37715-400 Poços de Caldas (MG), Brasil. \\ (*) Corresponding author: crsouza@epamig.br
}

Received: Feb. 4, 2015; Accepted: Mar. 16, 2015

\begin{abstract}
The performance of Syrah grapevine under protected cultivation with different plastic films was evaluated during 2012 and 2013 seasons in South of Minas Gerais State. Agronomical and physiological measurements were done on eight years old grapevines, grafted onto '1103 Paulsen' rootstock cultivated under uncovered conditions, covered with transparent and with diffuse plastic films. Both plastic covers induced the highest shoot growth rate and specific leaf area. The diffuse plastic induced greater differences on leaf area, pruning weight and leaf chlorophyll content as compared to uncovered vines. Grapevines under diffuse plastic also had the lowest rates of photosynthesis, stomatal conductance and transpiration. Leaf starch, glucose and fructose contents were not affected by treatment, but leaf sucrose was reduced by transparent plastic. The leaf and stem water potential were higher under diffuse plastic. In 2013, grapevines under diffuse plastic showed the highest yields mainly due to decreased rot incidence and increased cluster weight. Furthermore, berries under diffuse plastic showed the highest anthocyanins concentration. The use of diffuse plastic induces more agronomical benefits to produce Syrah grape under protected cultivation. Key words: Vitis vinifera, plastic cover, vegetative vigor, water relations, gas exchange, wine grape composition.
\end{abstract}

\section{INTRODUCTION}

In Minas Gerais State, the high rainfall during the summer is the main cause of quality loss of wine grape harvested during this season. Rain associated to humidity predisposes vine to mildew attack and increases the incidence of splitting, botrytis and other fungal disease in grapes (Jackson \& Lombard, 1993). Furthermore, excessive soil humidity due to high rainfall unbalances vegetative and reproductive development, elevates juice $\mathrm{pH}$ and acid content and reduces anthocyanins by shading due to continuous shoot growth (Dry \& Loveys, 1998).

Although double pruning management has improved the wine grape quality through changing the period of harvest from summer to autumn - winter (Regina et al., 2011), this technique could not be adopted in Caldas, a town located at high altitude $(1,150 \mathrm{~m})$ in the south of Minas Gerais State. The occurrence of freezing temperatures during the winter is responsible to impair the grape ripening, making the winter harvest unavailable.
An alternative to improve the wine grape quality harvested during the summer has been the use of plastic (polyethylene) covers to protect grapes and vines from rain damage. This recent innovation has been adopted in some Brazilian vineyards. The use of polyethylene cover in the vineyard has become widespread by wine grape growers to prevent diseases development, to reduce the use of fungicides, to increase the wine grape yield during the rainy summer and has also enabled organic table and wine grape production (Botelho et al., 2011; Chavarria et al., 2009; Chavarria \& Santos, 2009; Pedro et al., 2011). Besides elimination of negative effects like rain and diseases during grapevine growing season, the polyethylene cover has also shown to cause early ripening (Çoban, 2007) or delay harvest of grapes (Cangi et al., 2011; Kamiloglu et al., 2011). Furthermore, these studies have also revealed that microclimate alteration promoted by protected cultivations of grapevine has improved gas 
exchange and vine water status (Chavarria et al., 2008) and grape composition (Botelho et al., 2011).

Although the protected cultivation has favored plant health, ecophysiological performance, yield and quality improvement, there is an absence of published scientific data comparing different plastic materials on vine physiology, rot incidence or wine grape quality at harvest in southeast Brazilian climate conditions. Since the light absorption and transmission vary according to plastic physical properties, a more transparent plastic may have a greater effect on canopy temperatures, vine transpiration, and humidity as compared to translucent plastic. The purpose of this study was to evaluate the ecophysiological, biochemical and agronomical responses of field-grown 'Syrah' grapevine cultivated under uncovered vineyard and covered with two different plastic films during the rainy summer in Southern of Minas Gerais State.

\section{MATERIAL AND METHOD}

This trial was carried out in an experimental vineyard located in Caldas municipality, in the South of Minas Gerais State, at $22^{\circ} 55^{\prime} \mathrm{S}, 46^{\circ} 23^{\prime} \mathrm{W}$ and altitude of $1,150 \mathrm{~m}$, using eight years old 'Syrah' clone 747 - ENTAV-INRA grapevines grafted onto '1103 Paulsen' rootstock. The grapevines were spaced $1.5 \mathrm{~m}$ between vines and $2.5 \mathrm{~m}$ between rows north-south oriented, trained on a vertical shoot position and spur pruned with two spur nodes. The study was conducted during two growing seasons: 2012/2013 (2012 cycle) and 2013/2014 (2013 cycle). In 2012 cycle, the production pruning was done in August $21^{\text {th }}$ and the harvest in February $21^{\text {th }}, 2013$ whereas in 2013 cycle, the grapevines were pruned in August $27^{\text {th }}$ and the grapes were harvested in March $6^{\text {th }}, 2014$.

Three treatments in a completely randomized design were evaluated: uncovered vines, covered vines with diffuse polypropylene film $(0,100 \mu \mathrm{m}$ thickness, high diffuse radiation transmission, $82 \%$ light transmittance) and covered vines with transparent polypropylene film $(0,100 \mu \mathrm{m}$ thickness, 90\% light transmittance). For protected cultivation, in January 2012, plastic tunnels $95 \mathrm{~cm}$ higher from the last wire of the trellis system and $250 \mathrm{~cm}$ wide were installed in each row. Each treatment was represented by twenty six vines used for biochemical, ecophysiological and agronomical measurements during the experimental period.

The effects of plastic cover on vegetative vigor were evaluated by leaf area, shoot growth and pruning weight using eight to ten vines per treatment. The leaf area was estimated at pea berry stage following the methodology described in Regina et al. (2000). The mean rate of shoot growth $\left(\mathrm{cm} \mathrm{day}^{-1}\right)$ was calculated from shoot length measured weekly during October 2012 and 2013. The pruning weight per vine was obtained at the end of the winter. All shoots per vine were pruned and dried in a forced air oven at $60^{\circ} \mathrm{C}$ until constant weight was reached. The plastic cover effects on leaf thickness was evaluated by specific leaf area (SLA, leaf area per unit dry mass) using ten leaf discs of $3.14 \mathrm{~cm}^{2}$ per treatments (one leaf disc per vine). The leaf discs were oven-dried at $60{ }^{\circ} \mathrm{C}$ and their dry masses were determined.

The leaf gas exchange measurements were conducted on six fully mature and well-exposed leaves (one leaf per vine) with an LI-6400 infrared gas analyser (Li-Cor Inc., Lincoln, NE, USA) at late morning. Photosynthesis $(A)$, stomatal conductance $(g s)$, leaf transpiration $(E)$, photosynthetically active radiation $(P A R)$, leaf temperature $\left(\mathrm{T}_{\text {leaf }}\right)$ and leaf vapor pressure deficit (LVPD) were assessed. These measurements were evaluated only in 2012 growing season, during pea berry (October $29^{\text {th }}, 2012$ ) and berry ripening stages (January $7^{\text {th }}, 2013$ ). In both growing seasons, during the ripening period, the vine water status was evaluated by stem water potential $\left(\Psi_{\text {stem }}\right)$ and leaf water potential $\left(\Psi_{\text {leaf }}\right)$ measured on six to eight vines at late morning using pressure chamber model 3005 (Soilmoisture Equipement Corp., Santa Barbara, CA, USA. $\Psi_{\text {stem }}$ was measured on non-transpiring leaves that had been bagged with both plastic sheet and aluminum foil for at least $1 \mathrm{~h}$ before measurements. The leaf water potential was considered to be equal to stem water potential when leaf transpiration is prevented (Choné et al., 2001).

The soil moisture of vineyard, presented as volumetric water content (\% water by volume), was measured using a Time Domain Reflectometry probe equipped with $20 \mathrm{~cm}$ probe rods (Field Scout TDR 100, Spectrum Tecnologies, Inc., IL, USA). During the ripening period, the soil moisture readings were done at $20 \mathrm{~cm}$ and $40 \mathrm{~cm}$ in depth. For readings at $40 \mathrm{~cm}$ depth, the rods were inserted in the soil after removing the first $20 \mathrm{~cm}$ soil layer. In both depths, the readings were represented by the average from four positions around each vine (8 vines per treatment).

The leaf chlorophyll content was determined during the ripening period of both growing seasons. Fresh leaf discs of $3.14 \mathrm{~cm}^{2}$ were collected from eight vines per treatment (one leaf disc per vine) and kept in the dark at $-20{ }^{\circ} \mathrm{C}$. Chlorophyll pigments were extracted with acetone $80 \%$ in mortar and pestle. The solution was centrifuged (Hettich Universal 320R, UK) at 2,850.9 rpm for $5 \mathrm{~min}$. Chlorophyll concentration was determined spectrophotometrically by measuring the absorbance of the supernatant at 645 and $663 \mathrm{~nm}$ according to Arnon (1949).

Leaf soluble (glucose, fructose and sucrose) and insoluble (starch) carbohydrate concentration were assessed on dried and powered leaf samples taken from six grapevines per treatment during the ripening period. The carbohydrates were extracted from $100 \mathrm{mg}$ samples with $80 \%(\mathrm{v} / \mathrm{v})$ ethanol $\left(80^{\circ} \mathrm{C}, 20 \mathrm{~min}\right)$ and centrifuged $(9,160 \times \mathrm{x}, 15 \mathrm{~min})$. The pellet was extracted three times and the combined supernatants $(10 \mathrm{~mL})$ were used for the analyses of soluble sugars by enzymatic method (Bergmeyer, 1974). The leaf starch 
was quantified in the pellet after hydrolysis with Termamy ${ }^{\circledR}$ $120 \mathrm{~L}$ (diluted 1:500 in water) and incubation at $75^{\circ} \mathrm{C}$ for 1 hour, and with Amyloglucosidase $300 \mathrm{~L}$ ( 28 unit $\mathrm{mL}^{-1}$, in sodium acetate buffer, $\mathrm{pH} 4.8$ ) and incubation at $50^{\circ} \mathrm{C}$ for 1 hour. The released glucose was quantified colorimetrically at $450 \mathrm{~nm}$ using glucose oxidase/peroxidase/ABTS assay (Bergmeyer, 1974). Starch content was calculated as glucose multiplied by 0.9 .

The number and weight of clusters and the yield per vine were measured on ten vines per treatment at harvest. Chemical analyses (soluble solids, $\mathrm{pH}$ and titratable acidity) were performed on the juice of pressed berries (10 replicates of 50 berries samples per treatment) collected, at harvest, from all vines and representative of all cluster positions within the canopy and of all positions within the cluster. Soluble solids ( ${ }^{\circ}$ Brix) were determined using a handheld temperature compensated refractometer (ATAGO Model Pal-1). The $\mathrm{pH}$ of undiluted juice of each sample was determined using a pHmeter (Micronal B474) and titratable acidity was determined by titration with $0.1 \mathrm{~N} \mathrm{NaOH}$ to a phenolphthalein end point and expressed as $\mathrm{g} \mathrm{L}^{-1}$. Skins were weighed separately, frozen in liquid $\mathrm{N}_{2}$ and stored at $-20{ }^{\circ} \mathrm{C}$ until analysis. For anthocyanins analyses, skins were placed in tubes containing $8 \mathrm{~mL}$ of acidified methanol $(1 \% \mathrm{HCl}, \mathrm{v} / \mathrm{v})$, homogenized with an Ultra-Turrax apparatus (model B14, Digimed, São Paulo, Brazil) at 14,000 rpm for $1 \mathrm{~min}$ and stored in darkness at $10^{\circ} \mathrm{C}$ for 16 hours. Samples were centrifuged at 7,298 g for $15 \mathrm{~min}$ and the precipitate washed with acidified methanol until complete removal of pigments. The supernatant was collected in $50 \mathrm{~mL}$ volumetric flasks and used for anthocyanins analyses. Anthocyanins were measured by the $\mathrm{pH}$ differential method (Giusti \& Wrolstad, 2000) and the concentration (expressed as $\mathrm{mg}$ pigment/g berry skin) was determined using the molecular weight $(529)$ and molar absorbance $(28,000)$ values for malvidin-3-glucoside (Bergqvist et al., 2001). Rot incidence (the rate of diseased berry per cluster) was evaluated by a scale note classified according to Favero et al. (2011): (1) absence of symptoms; (3) visible symptoms up to $10 \%$; (5) symptoms up to $30 \%$; (7) symptoms between $30 \%$ and $50 \%$; (9) very strong attack, above $50 \%$.

Air temperature (near to the cluster zone) and incoming solar radiation were monitored in all treatments using a meteorological station's daily weather recordings (each 30 minutes) (Onset HOBO Weather Station, MA, USA). Temperature sensors were positioned in the middle of canopy and the pyranometer, at $30 \mathrm{~cm}$ below the plastic cover. The meteorological data were recorded during the month of October in 2012 (shoot growth period) and January 2013 (ripening period).

All data sets were subjected to analyses of variance (ANOVA) using the STATISTICA software (ver. 5.0, Statsoft, Inc. Tulsa, OK, USA). A completely randomized design was used. For all variables a two way ANOVA was used with treatment and year as the main factors. For gas exchange variables a two way ANOVA was used with treatment and month as the main factors. Tukey HSD tests $(\mathrm{p}=0.05)$ were carried out to determine differences between treatments means.

\section{RESULTS AND DISCUSSION}

As expected, the light environment on vineyard was more influenced by plastic covers than air temperatures (Table 1). The incoming solar radiation measured in both months decreased around 15\% under transparent plastic and $32 \%$ under diffuse plastic as compared to uncovered treatment. Near to the cluster zone, the highest temperatures were observed under transparent plastic and uncovered treatment, mainly in the maximum temperature. However, these differences were not so large and it could be attributed to the open structure of plastic tunnels that allowed the lateral air circulation favoring the heat loss.

In both growing seasons, there was no effect of plastic type on shoot growth rate and SLA and in both treatments the values were higher than in uncovered vines (Figures 1a,b). However, the most differences on leaf area and pruning weight were observed between vines growing under diffuse plastic and uncovered environment in both years (Figures 1c,d). These variables were increased by transparent plastic only in 2013 season. The leaf area and SLA results indicate an adaptive mechanism of grapevines in response to low irradiance caused by plastic cover, implying an immediate increase investment in photosynthesizing leaf area rather than in dry weight. Increased SLA under plastic cover also confirms that individual leaves were larger but thinner. It is

Table 1. Maximum (Tmax), minimum temperatures (Tmin) and incoming solar radiation (ISR) of the canopy of Syrah grapevine under uncovered and covered with diffuse and transparent plastic films, during the shoot growing (October 2012) and ripening period (January 2013) of 2012 growing season

\begin{tabular}{|ccccccccccc}
\hline & \multicolumn{3}{c}{$\operatorname{Tmax}\left({ }^{\circ} \mathbf{C}\right)$} & \multicolumn{3}{c}{$\operatorname{Tmin}\left({ }^{\circ} \mathbf{C}\right)$} & \multicolumn{3}{c}{ ISR $\left(\mathbf{W} \mathbf{~ m}^{-2}\right)$} \\
\hline Month & Diffuse & Transp. & Uncov. & Diffuse & Transp. & Uncov. & Diffuse & Transp. & Uncov \\
\hline Oct 12 & 28.1 & 30.7 & 31.9 & 12.5 & 12.1 & 11.9 & 167.4 & 216.3 & 249.6 \\
\hline Jan 13 & 31.3 & 34.4 & 32.8 & 12.0 & 11.7 & 11.8 & 134.7 & 160.4 & 193.4 \\
\hline
\end{tabular}

Means values of daily measures. (Tmax) maximum temperature; (Tmin) minimum temperature (Uncov) grapevine uncovered; (Transp) grapevine covered with transparent plastic. 
well known in the literature that less structural material per unit area is accumulated in the leaves in response to low-light stress (Chavarria et al., 2012; Poorter et al., 2009; Terashima et al., 2006).

The main shoot growth rate and pruning weight also increased under plastic covered probably due, mainly, to the highest minimum air temperature (Table 1 ) as compared to uncovered treatments (Figures 1a,d). The shoot growth is highly dependent on air temperature, being linearly related to thermal time for all stages of leaf development from budbreak to veraison (Borghezan et al., 2012; Lebon et al., 2004). Furthermore, the high night temperature may have increased the respiration activity providing more energy and carbon skeleton for shoot growth of covered grapevine (Hendrickson et al., 2004).

In general, the photosynthetic parameters measured during the shoot growing (October) and ripening period (January) were significantly reduced by diffuse plastic as compared to transparent plastic and uncovered treatments (Table 2). The PAR was reduced around $70 \%$ by diffuse plastic

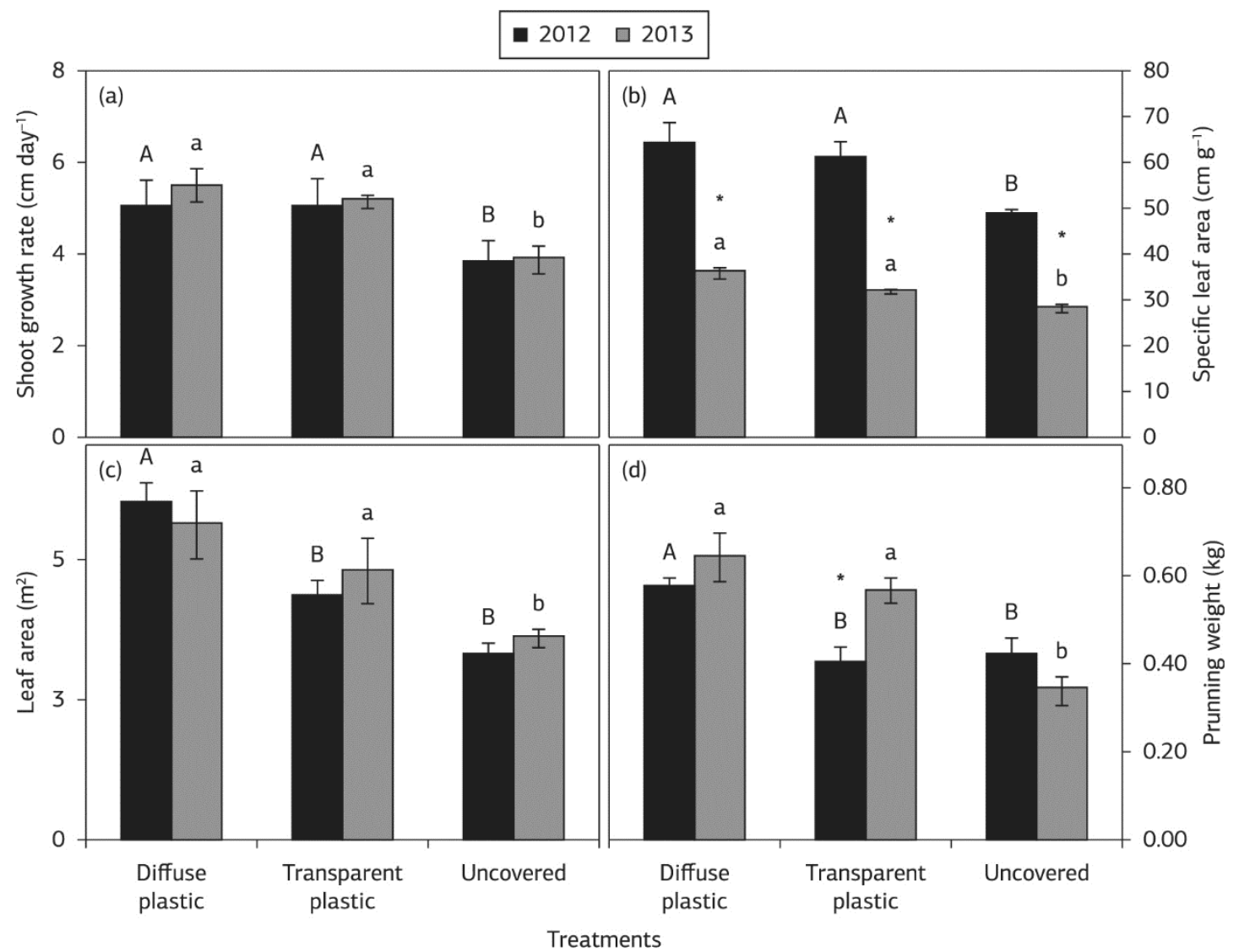

Figure 1. Shoot growth rate (a), specific leaf area (SLA, b), leaf area (c) and pruning weight (d) of uncovered 'Syrah' grapevine and covered with diffuse and transparent plastic in 2012 and 2013 growing seasons. Each point is the mean \pm standard error. Same uppercase (2012) or lowercase (2013) letters do not differ significantly among treatments per season as determined by Tukey test $(\mathrm{p}<0.05) .{ }^{*}=$ significant difference between seasons $(\mathrm{p}<0.05)$.

Table 2. Photosynthesis $(A)$, stomatal conductance $(g s)$, leaf transpiration $(E)$, photosynthetically active radiation $(P A R)$, leaf temperature $\left(\mathrm{T}_{\text {leaf }}\right)$ and leaf vapor pressure deficit (LVPD) of 'Syrah' grapevine growing under uncovered and covered with diffuse plastic and transparent plastic during shoot growing (October 2012) and ripening (January 2013) period of 2012 growing season

\begin{tabular}{|c|c|c|c|c|c|c|c|c|c|c|c|c|}
\hline \multirow{3}{*}{ Treatments } & \multicolumn{2}{|c|}{ A } & \multicolumn{2}{|c|}{ gs } & \multicolumn{2}{|c|}{ E } & \multicolumn{2}{|c|}{ PAR } & \multicolumn{2}{|c|}{$T_{\text {leaf }}$} & \multicolumn{2}{|c|}{ LVPD } \\
\hline & \multicolumn{2}{|c|}{$\mu \mathrm{mol} \mathrm{m}^{-2} \mathrm{~s}^{-1}$} & \multicolumn{2}{|c|}{ 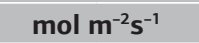 } & \multicolumn{2}{|c|}{$\mathrm{mmolm}^{-2} \mathrm{~s}^{-1}$} & \multicolumn{2}{|c|}{$\mu \mathrm{mol} \mathrm{m}^{-2} \mathrm{~s}^{-1}$} & \multicolumn{2}{|c|}{${ }^{\circ} \mathrm{C}$} & \multicolumn{2}{|c|}{$\mathrm{kPa}$} \\
\hline & Oct & Jan & Oct & Jan & Oct & Jan & Oct & Jan & Oct & Jan & Oct & Jan \\
\hline & 2012 & 2013 & 2012 & 2013 & 2012 & 2013 & 2012 & 2013 & 2012 & 2013 & 2012 & 2013 \\
\hline Diffuse & $12.2 \mathrm{Ba}$ & $10.8 \mathrm{Ba}$ & $0.4 \mathrm{Ba}$ & $0.3 \mathrm{Bb}$ & 7.1Ca & $6.1 \mathrm{Ca}$ & $556 \mathrm{Ca}$ & $488 \mathrm{Cb}$ & $29.2 \mathrm{Ba}$ & $30.7 \mathrm{Ba}$ & $1.8 \mathrm{Ba}$ & $2.3 \mathrm{Ba}$ \\
\hline Transparent & 15.9Aa & 15.1Aa & $0.5 \mathrm{Aa}$ & $0.4 \mathrm{Ab}$ & $9.2 \mathrm{Ba}$ & $9.2 \mathrm{Ba}$ & $1185 \mathrm{Ba}$ & $1005 B b$ & $31.5 \mathrm{ABa}$ & $32.6 \mathrm{ABa}$ & 2.2ABa & 2.4ABa \\
\hline Uncovered & $15.7 \mathrm{Aa}$ & $15.8 \mathrm{Aa}$ & $0.5 \mathrm{Aa}$ & $0.4 \mathrm{Ab}$ & $10.3 \mathrm{Aa}$ & 10.9Aa & 1790Aa & $1710 A a$ & $33.2 \mathrm{Aa}$ & 34.9Aa & $2.5 \mathrm{Aa}$ & 2.9Aa \\
\hline
\end{tabular}

Same uppercase (for treatments) and lowercase (for month) letter do not differ significantly as determined by Tukey test $(\mathrm{p}<0.05)$. 
as compared to $39 \%$ by transparent plastic. The grapevine covered by diffuse plastic showed the lowest $A$, gs, $E$, LVPD and $\mathrm{T}_{\text {leaf }}$ The $A$ and gs were less affected by transparent plastic and the values were similar to observed for uncovered vines. However, the grapevines covered with transparent plastic showed intermediate values of $E$, Tleaf and LVPD. Although the PAR under diffuse plastic remained below the light saturation for grapevine $\left(1000 \mu \mathrm{mol} \mathrm{m}^{-2} \mathrm{~s}^{-1}\right.$; Table 2$)$, the values of $A$ and gs remained in the range usually found under non-stressful field conditions (Mullins et al., 1992, Souza et al., 2003). In the other hand, the increased leaf area by diffuse plastic may have contributed to canopy carbon assimilation. Furthermore, the thermal conditions under diffuse plastic were more favorable to photosynthetic activity as showed by the lowest values of $\mathrm{T}_{\text {leaf }}$ and LVPD.

In both growing seasons, the leaf chlorophyll content was increased by diffuse plastic as compared to uncovered vines (Figures 2a,b). The vines under transparent plastic only showed differences from uncovered vines in 2013 season (Figure $2 \mathrm{~b}$ ). The decreased thickness of leaf parenchyma tissues by solar radiation restriction as showed by high SLA values contributed to the highest values of leaf chlorophyll on covered vines. This result was also confirmed by changes in leaf anatomy and increased chlorophyll content of grapevines under protected cultivation to compensate the light restriction by plastic film as showed by Chavarria et al. (2012). Higher differences found between diffuse plastic and uncovered may be attributed to the lowest radiation transmission by this plastic material as compared to transparent plastic.

In both growing seasons, the leaf concentration of starch, glucose and fructose were not affected by plastic cover whereas the leaf sucrose content was reduced only by transparent plastic (Figure 3). The sucrose content was higher than starch and reducing sugars in all treatments. The most predominant sugar on a dry weight basis in grapevine leaves is sucrose, as already shown by Grant et al. (2009). The explanation for sucrose reduction by transparent film may be related to thermal conditions of canopy under this plastic type. The sucrose reduction could be associated to limitation of sucrose synthesis or/and increased sucrose hydrolysis promoted by the high leaf temperature (up to $30^{\circ} \mathrm{C}$ ) observed under transparent plastic. Uncovered vines, on the other hand, also showed higher leaf temperature but its sucrose content also increased. Studies regarding the effect of high temperature on leaf sucrose concentrations are contradictory in the literature. Heat stress increased accumulation of foliar sucrose in potato mature leaves (Lafta \& Lorenzen, 1995) and decreased in sugarcane leaves (Ebrahim et al., 1998). The high sucrose accumulation on leaf of uncovered vines can be associated to its reduced leaf area, since sucrose synthesized in the cytosol can be either temporally stored within leaf or translocated from the leaves to sustain cell maintenance and fuel growth of sink tissues (Taiz \& Zeiger, 1991).

During the ripening period, the effect of protected cultivation on soil moisture showed by volumetric water content (VWC) was more pronounced at $40 \mathrm{~cm}$ depth only in 2013 growing season (Figure 4a, b). The soil under diffuse plastic showed the lowest VCW as compared to uncovered soil whereas there was no difference on soil moisture between transparent plastic and uncovered treatment. The highest leaf area (Figure 1c) associated with high yield (Table 3) increased the soil water consumption under diffuse plastic treatment.

Despite this reduction on soil moisture and the highest canopy size, the vines under diffuse plastic showed the highest (less negative) values of leaf $\left(\Psi_{\text {leaf }}\right)$ and stem $\left(\Psi_{\text {stem }}\right)$ water potential (Figure 5). It is well known that these indicators of leaf water status reflect soil water availability, but they also depend on atmospheric conditions, specifically atmospheric

\section{- Chl a $\square$ Chl b $\square$ Chl total}

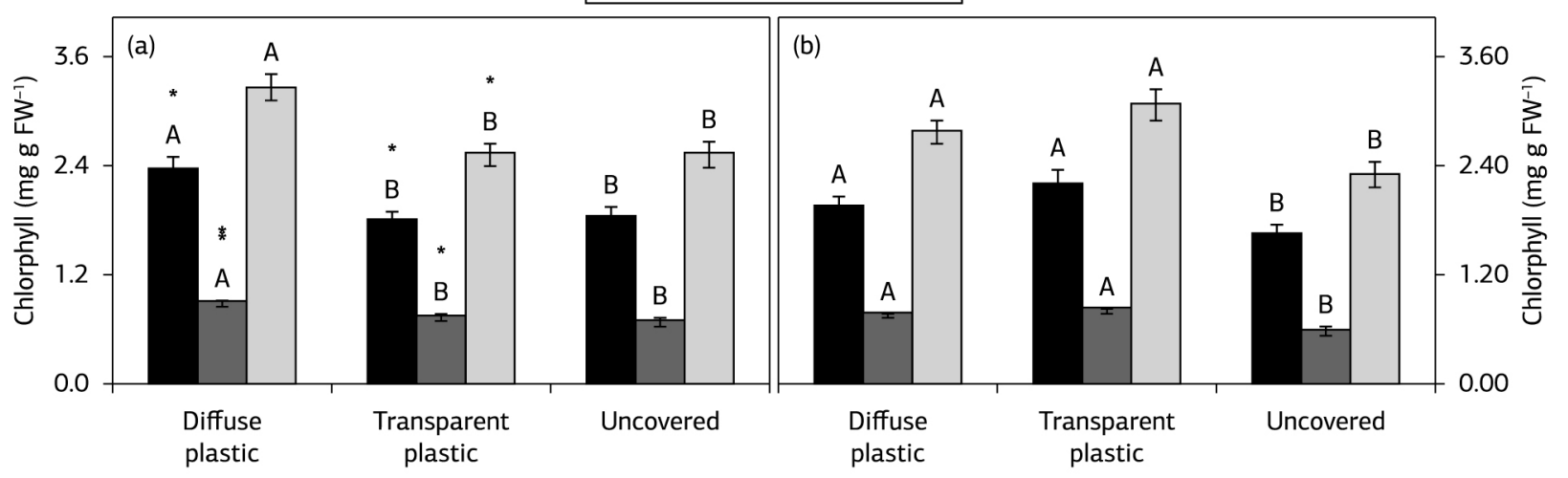

Treatments

Figure 2. Leaf chlorophyll contents ( $\mathrm{a}, \mathrm{b}$ and total) of 'Syrah' grapevine growing under uncovered environment and covered with diffuse and transparent plastic in 2012 (a) and 2013 (b) seasons. Each bar is the mean \pm standard error. Same letter do not differ significantly as determined by Tukey test $(\mathrm{p}<0.05){ }^{*}=$ significant difference between years $(\mathrm{p}<0.05)$. 
evaporative demand (van Leeuwen et al., 2009). Probably the lowest evaporative demand associated to the lowest stomatal conductance and leaf transpiration under diffuse plastic, as showed in table 2 , contributed to avoid the reduction on $\Psi_{\text {stem }}$. Furthermore, the grapevine has been considered a water stress avoiding species and stomatal conductivity is regulated to control leaf water deficit, and to prevent permanent leaf damage (Schultz, 2003). The highest light

[ $2012 \square 2013$

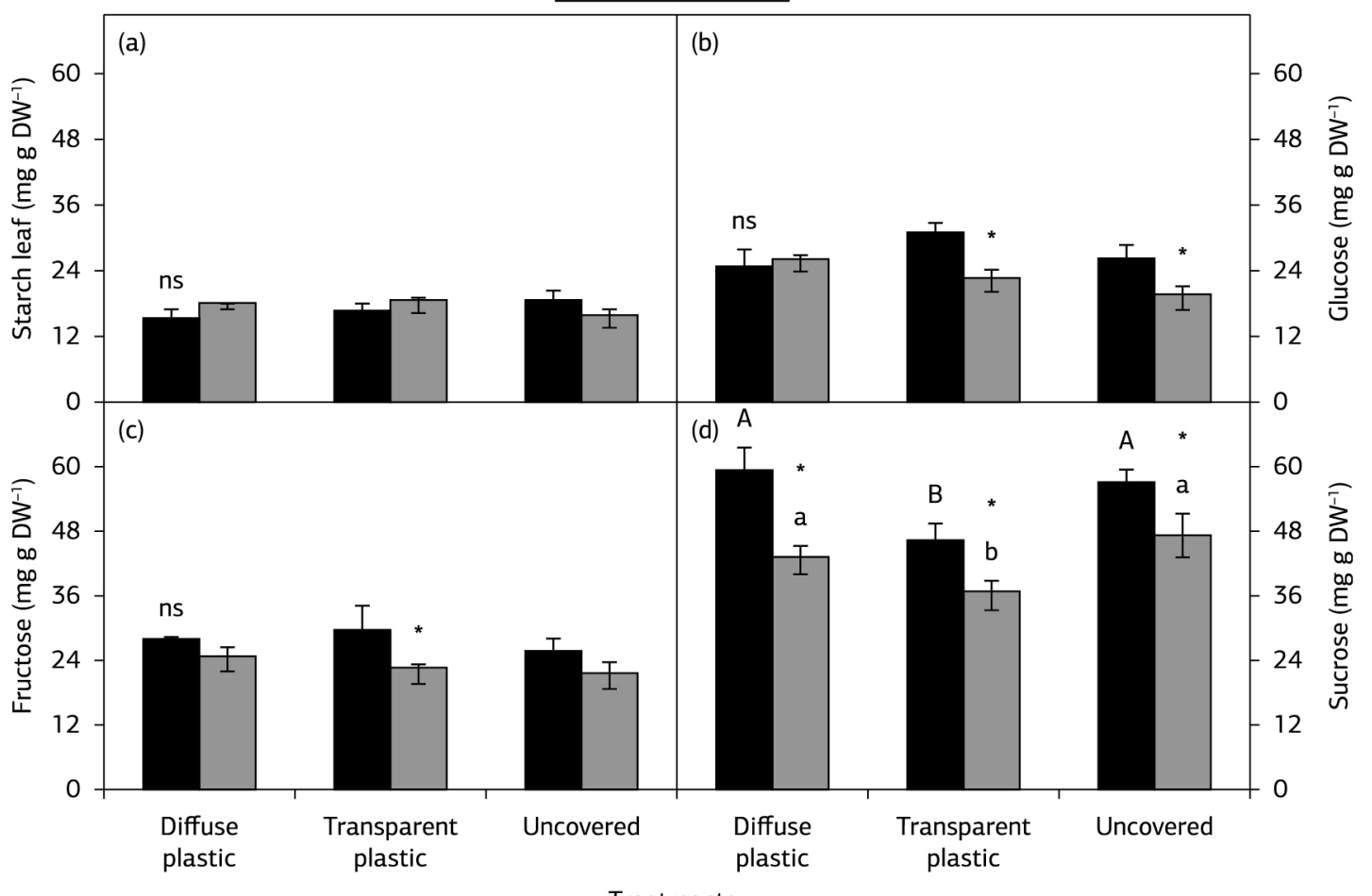

Treatments

Figure 3. Starch (a), glucose (b), fructose (c) and sucrose (d) contents in leaves of 'Syrah' grapevines growing under uncovered environment and covered with diffuse and transparent plastic during 2012 and 2013 growing seasons. Each bar is the mean \pm standard error. Same uppercase (2012) and lowercase (2013) letter do not differ significantly as determined by Tukey test $(\mathrm{p}<0.05)$. ns = no significant differences $(\mathrm{p}>0.05) .^{*}=$ significant difference between years $(\mathrm{p}<0.05)$.

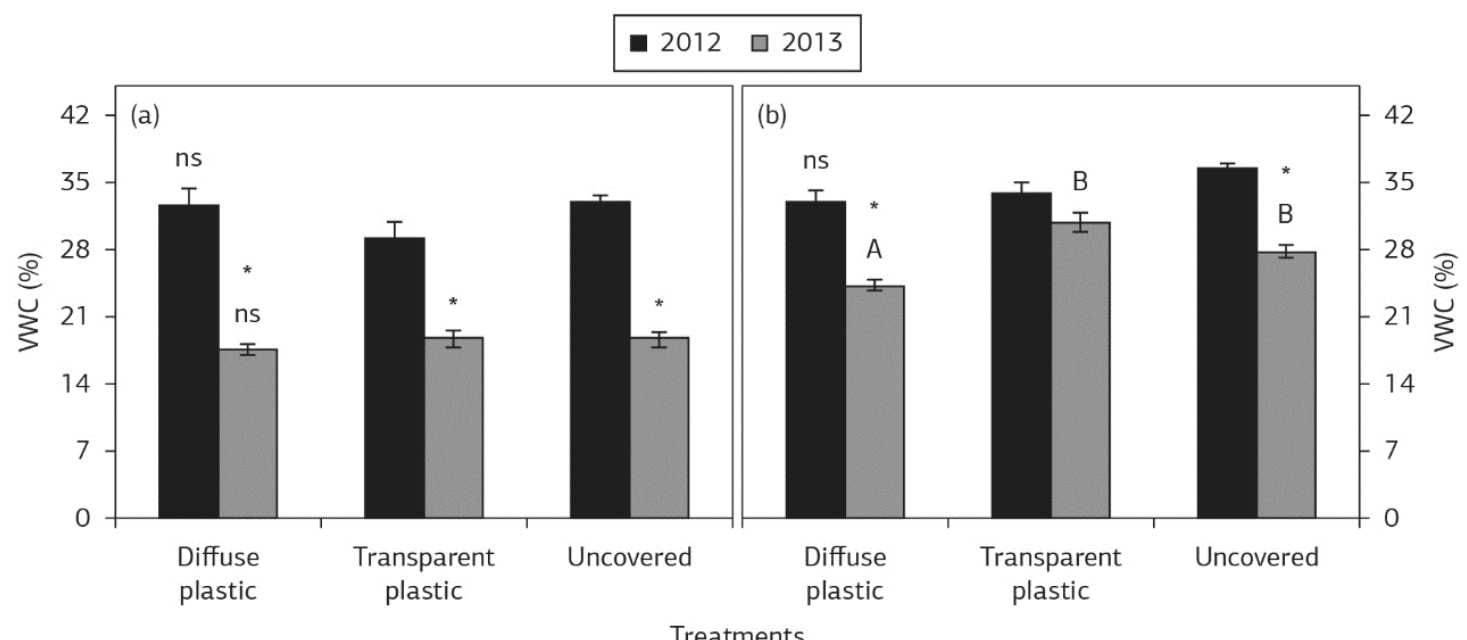

Figure 4. Effect of uncovered environment and plastic cover (diffuse and transparent films) on volumetric soil water content (VWC) at 20 $\mathrm{cm}$ (a) and $40 \mathrm{~cm}$ depth (b) of 'Syrah' grapevine during 2012 and 2013 growing seasons. Each bar is the mean \pm standard error. Same letter do not differ significantly as determined by Tukey test $(\mathrm{p}<0.05)$. ns $=$ no significant differences $(\mathrm{p}>0.05) .{ }^{*}=$ significant difference between years $(\mathrm{p}<0.05)$. 


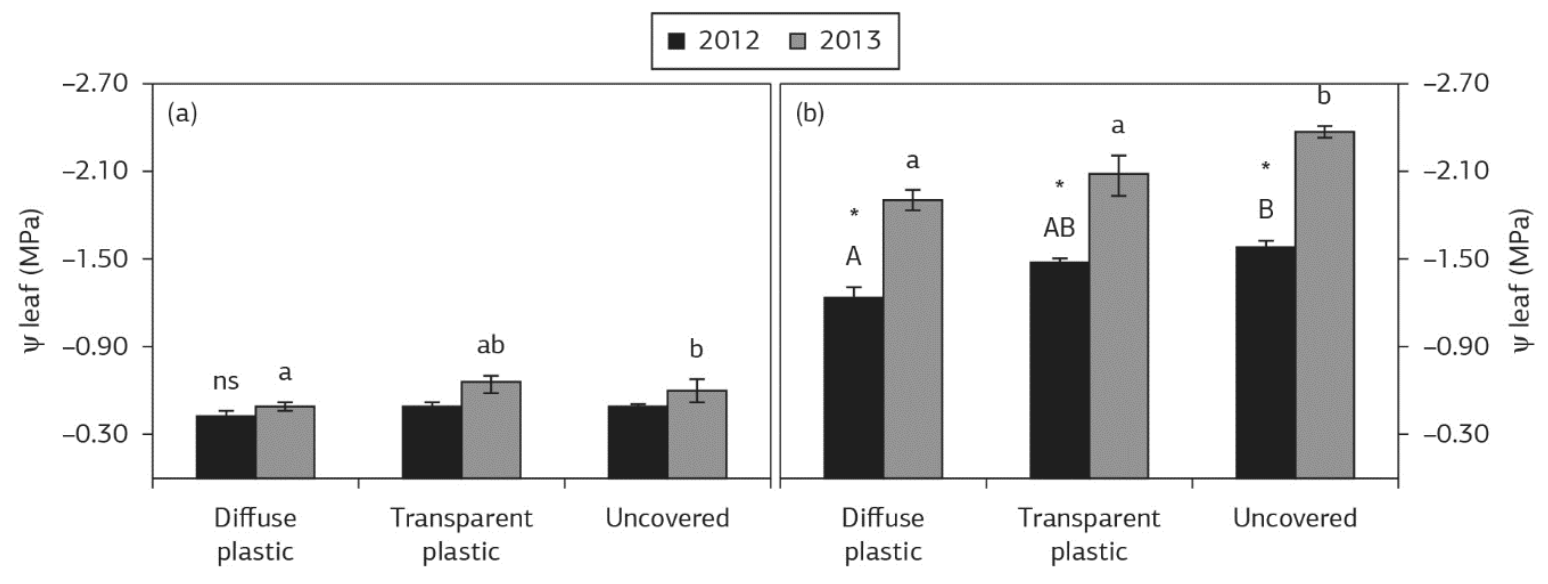

Treatments

Figure 5. Effect of uncovered environment and plastic cover (diffuse and transparent plastic) on stem ( $\Psi$ stem, a) and leaf water potential ( $\Psi$ leaf, b) of 'Syrah' grapevine during 2012 and 2013 growing season. Each bar is the mean \pm standard error. Same letter do not differ significantly as determined by Tukey test $(\mathrm{p}<0.05)$. ns $=$ no significant differences $(\mathrm{p}>0.05) .{ }^{*}=$ significant difference between years $(\mathrm{p}<0.05)$.

Table 3. Yield components, rot incidence and berry quality parameters ( $\mathrm{pH}$, total soluble solids (TSS), total acidity (TA) and anthocyanins) at harvest of 'Syrah' grapevine growing under uncovered and covered (diffuse and transparent plastic) conditions during 2012 and 2013 growing seasons.

\begin{tabular}{|c|c|c|c|c|c|c|c|c|}
\hline \multirow{4}{*}{ Treatment } & \multicolumn{6}{|c|}{ Yield components } & \multicolumn{2}{|c|}{ Rot Incidence } \\
\hline & \multirow{2}{*}{\multicolumn{2}{|c|}{$\begin{array}{c}\text { Cluster vine }^{-1} \\
\text { unity }\end{array}$}} & \multirow{2}{*}{\multicolumn{2}{|c|}{$\begin{array}{c}\text { Cluster weight } \\
\text { g }\end{array}$}} & \multicolumn{2}{|c|}{ 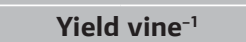 } & & \\
\hline & & & & & & & \multicolumn{2}{|c|}{ Index } \\
\hline & 2012 & 2013 & 2012 & 2013 & 2012 & 2013 & 2012 & 2013 \\
\hline Diffuse & 33.9Aa & $39.1 \mathrm{Aa}$ & $85.3 \mathrm{Bb}$ & $166.6 \mathrm{Aa}$ & $3.0 A b$ & $6.5 \mathrm{Aa}$ & 3.5Ba & $2.3 \mathrm{Cb}$ \\
\hline Transparent & $33.4 \mathrm{Aa}$ & $28.1 \mathrm{Ba}$ & $111.5 \mathrm{Aa}$ & $122.6 \mathrm{Ba}$ & 3.7Aa & $3.5 \mathrm{Ba}$ & $2.6 \mathrm{Bb}$ & $3.6 \mathrm{Ba}$ \\
\hline Uncovered & $36.5 \mathrm{Aa}$ & $30.8 \mathrm{ABa}$ & $25.1 \mathrm{Cb}$ & $123.1 \mathrm{Ba}$ & $0.9 \mathrm{Bb}$ & $3.8 \mathrm{Ba}$ & 8.7Aa & $4.6 \mathrm{Ab}$ \\
\hline \multirow{4}{*}{ Treatment } & & & \multicolumn{6}{|c|}{ Quality parameters } \\
\hline & \multirow{2}{*}{\multicolumn{2}{|c|}{$\mathrm{pH}$}} & \multicolumn{2}{|c|}{ TSS } & \multicolumn{2}{|c|}{ TA } & \multicolumn{2}{|c|}{ Anthocyanins } \\
\hline & & & \multicolumn{2}{|c|}{${ }^{\circ}$ Brix } & \multicolumn{2}{|c|}{$\mathrm{g} \mathrm{L}^{-1}$} & \multicolumn{2}{|c|}{ mg g berry ${ }^{-1}$} \\
\hline & 2012 & 2013 & 2012 & 2013 & 2012 & 2013 & 2012 & 2013 \\
\hline Diffuse & $3.5 \mathrm{Ab}$ & $3.8 \mathrm{Aa}$ & $20.6 A a$ & $19.9 \mathrm{Ab}$ & 7.7Ba & $5.3 \mathrm{Ab}$ & $0.5 \mathrm{Ab}$ & $0.9 \mathrm{Aa}$ \\
\hline Transparent & $3.4 \mathrm{Bb}$ & $3.8 \mathrm{Aa}$ & $20.1 \mathrm{Ba}$ & $19.8 \mathrm{Aa}$ & $6.8 \mathrm{Ca}$ & $5.5 \mathrm{Ab}$ & $0.5 \mathrm{Ab}$ & $0.6 \mathrm{Ba}$ \\
\hline Uncovered & $3.4 \mathrm{Bb}$ & 3.7Ba & $18.2 \mathrm{Ca}$ & $18.5 \mathrm{Ba}$ & $9.9 \mathrm{Aa}$ & $5.5 \mathrm{Ab}$ & $0.5 \mathrm{Ab}$ & $0.7 \mathrm{Ba}$ \\
\hline
\end{tabular}

Same uppercase (for treatments) and lowercase (for year) letter do not differ significantly as determined by Tukey test $(\mathrm{p}<0.05)$.

restriction observed under diffuse plastic (Tables 1 and 2) may also have contributed to reduce the stomatal aperture (Table 2) since the stomata behavior is also influenced by light (Taiz \& Zeiger, 1991). Hence, the reduced transpiration per leaf under plastic diffuse maintained the $\Psi_{\text {stem }}$ values higher than leaf under transparent plastic and uncovered treatments. On the other hand, the reduced leaf transpiration was not enough to avoid the higher soil water consumption (Figure 4) promoted by increased canopy size (Figure 1).

Only in 2013 growing season, the lowest $\Psi_{\text {stem }}$ values indicated mild water deficit (around -0,6 $\mathrm{MPa}$ ) whereas the lowest $\Psi_{\text {leaf }}$ a severe water deficit $(<-1,4 \mathrm{MPa})$ according to van Leeuwen, et al. (2009). These indicators reached the critical values due to an exceptional decrease in precipitation during January 2014 (46 mm) compared to a historical mean of January 2013 (379 mm) (Tonietto et al., 2006).
However, in all treatments the vines did not show visible water stress symptoms such as yellowing leaves at the base, leaf angle reduction and wilting (Deloire et al., 2004). These results suggest that both water status indicators were more influenced by atmospheric evaporative demand than soil water availability.

The soil water reduction under diffuse plastic did not compromise the yield. In contrast, the yield was significantly increased by this plastic type in 2013 season due to the highest cluster number and the lowest rot incidence (Table 3). In general, the rot incidence was reduced in both plastic covers. However, in the driest growing season, the rot incidence was lower under diffuse than transparent plastic. The high temperature and moisture condensation under transparent plastic could have favored more fungal infection as also observed by Cangi et al. (2011). Despite the 
differences on cover material, the protected cultivation has been very useful to control the fungal diseases and reduce the chemical control in vineyards as showed by several authors (Cangi et al., 2011; Comiran et al., 2012). The low rainfall during the ripening period of 2013 growing season also reduced rot incidence under uncovered vines.

There was significant interaction between treatment and years on grape quality parameters (Table 3). As also expected, the lowest grape quality was observed from uncovered vines. This treatment showed the lowest soluble solids sugars and $\mathrm{pH}$ and the highest acidity as compared to covered vines (Table 3). The effects of plastic cover on anthocyanins concentration were only observed during 2013 growing season, where grapes from diffuse plastic showed the highest color intensity. Nowadays, there is a contradictory data in the literature regarding the light effects on grape anthocyanins contents. Some studies showed changes in total anthocyanin by shading whereas others reported that high light resulted in low anthocyanins contents (Downey et al., 2006). In our study, the anthocyanins content probably was more influenced by temperature than light conditions. The reduced anthocyanin levels in uncovered and transparent plastic were probably due to the highest temperature observed in these treatments. High temperature may compromise the anthocyanins accumulation due to many factors such as anthocyanin degradation (chemical and/or enzymatic) and inhibition of biosynthetic genes (Mori et al., 2007). The highest radiation reduction caused by diffuse plastic contributed to avoid the temperature increasing and its negative effects on grape composition.

\section{CONCLUSION}

During the rainy summer, the use of plastic cover showed positive effect on vegetative and reproductive development of Syrah vineyard. Under protected cultivation, the grapevines showed the highest shoot growth rate, leaf area, chlorophyll contents and yield whereas the rot incidence was reduced. However, under the driest year, the diffuse plastic increased yield and grape color intensity as compared to transparent plastic. Furthermore the greatest alterations in the grapevine development were induced by diffuse plastic as compared to uncovered vineyard.

\section{ACKNOWLEDGEMENTS}

This research was funded by Fundação de Amparo a Pesquisa do Estado de Minas Gerais (FAPEMIG). The authors are also grateful to Electroplastic and Anjos \& Souza Ltda for technical assistance in the plastic cover installation.

\section{REFERENCES}

Arnon, D. I. (1949). Copper enzymes in isolated chloroplasts: polyphrenol oxidase in Beta vulgaris. Plant Physiology, 24, 1-15. http://dx.doi.org/10.1104/pp.24.1.1. PMid:16654194.

Bergmeyer, H. U. (1974). Methods of enzymatic analysis. New York: Academic Press.

Bergqvist, J., Dokoozlian, N., \& Ebisuda, N. (2001). Sunlight exposure and temperature effects on berry growth and composition of cabernet sauvignon and grenache in the central San Joaquin Valley of California. American Journal of Enolology and Viticulture, 52, 1-7

Borghezan, M., Gavioli, O., Vieira, H. J., \& Silva, A. L. (2012). Shoot growth of Merlot and Cabernet Sauvignon grapevine varieties. Pesquisa Agropecuaria Brasileira, 47, 200-207. http://dx.doi.org/10.1590/ S0100-204X2012000200008.

Botelho, R. V., Pavanello, A. P., Pires, E. J. P., Terra, M. M., \& Müller, M. M. L. (2011). Produçáo orgânica de uvas para vinho tinto sob cobertura plástica em regiáo subtropical do Brasil. Ciência e Agrotecnologia, 35, 1186-1195. http://dx.doi.org/10.1590/S141370542011000600020 .

Cangi, R., Yağcl, A., Akgul, S., Kesgin, M., \& Yanar, Y. (2011). Effects of shading and covering material application for delaying harvest on gray mold disease severity. African Journal of Biotechnology, 10, 12182-12187.

Chavarria, G., \& Santos, H. P. (2009). Manejo de videiras sob cultivo protegido. Ciência Rural, 39, 1917-1924. http://dx.doi.org/10.1590/ S0103-84782009005000104.

Chavarria, G., Santos, H. P., Castro, L. A. S., Marodin, G. A. B., \& Bergamaschi, H. (2012). Anatomy, chlorophyll content and photosynthetic potential in grapevine leaves under plastic cover. Revista Brasileira de Fruticultura, 34, 661-668. http://dx.doi.org/10.1590/ S0100-29452012000300003.

Chavarria, G., Santos, H. P., Felippeto, J., Marodin, G. A. B., Bergamaschi, H., Cardoso, L. S., \& Fialho, F. B. (2008). Relaçóes hídricas e trocas gasosas em vinhedo sob cobertura plástica. Revista Brasileira de Fruticultura, 30, 1022-1029. http://dx.doi.org/10.1590/ S0100-29452008000400030.

Chavarria, G., Santos, H. P., Mandelli, F., Marodin, G. A. B., Bergamaschi, H., \& Cardoso, L. S. (2009). Potencial produtivo de videiras cultivadas sob cobertura plástica. Pesquisa Agropecuaria Brasileira, 44, 141-147. http://dx.doi.org/10.1590/S0100-204X2009000200005.

Choné, X., Van Leeuwen, C., Dubourdieu, D., \& Gaudillère, J. P. (2001). Stem water potential is a sensitive indicator of grapevine water status. Annals of Botany, 87, 477-483. http://dx.doi.org/10.1006/ anbo. 2000.1361 .

Çoban, H. (2007). Effects of plastic covering on yield, physical and chemical characteristics of some table grapes (Vitis vinifera L.). Asian Journal of Chemistry, 19, 4052-4058.

Comiran, F., Bergamaschi, H., Heckler, B. M. M., Santos, H. P., Alba, D., \& Saretta, E. (2012). Microclima e produçáo de videira 'Niágara Rosada' em cultivo orgânico sob cobertura plástica. Revista Brasileira de Fruticultura, 34, 152-159. http://dx.doi.org/10.1590/ S0100-29452012000100021. 
Deloire, A. A., Carbonneau, A., Wang, Z. P., \& Ojeda, H. (2004). Vine and water: a short review. Journal International des Sciences de la Vigne et du Vin, 38, 1-13.

Downey, M. P., Dokoozlian, N. K., \& Krstic, M. (2006). Cultural practice and environmental impacts on the falvonoid composition of grapes and wine: a review of recent research. American Journal of Enology and Viticulture, 57, 257-268.

Dry, P. R., \& Loveys, B. R. (1998). Factors influencing grapevine vigour and the potential for control with partial rootzone drying. Australian Journal of Grape and Wine Research, 4, 140-148. http:// dx.doi.org/10.1111/j.1755-0238.1998.tb00143.x.

Ebrahim, M. K., Zingsheim, O., El-Shourbagy, M. N., Moore, P. H., $\&$ Komor, E. (1998). Growth and sugar storage in sugarcane grown at temperatures below and above optimum. Journal of Plant Physiology, 153, 593-602. http://dx.doi.org/10.1016/S0176-1617(98)80209-5.

Favero, A. C., Amorim, D. A., Mota, R. V., Soares, A. M., Souza, C. R., \& Regina, M. A. (2011). Double-pruning of "Syrah" grapevines: a management strategy to harvest wine grapes during the winter in the Brazilian Southeast. Vitis, 50, 151-158.

Giusti, M. M., \& Wrolstad, R. E. (2000). Characterization and measurement of anthocyanins by uvvisible spectroscopy (Current Protocols in Food Analytical Chemistry). New York: John Willey \& Sons. Retrieved in 20 March 2010, from http://www.does.org/ masterli/facsample.htm.

Grant, T. N., Dami, I. E., Ji, T., Scurlock, D., \& Streeter, J. (2009). Variation in leaf and bud soluble sugar concentration among Vitis Genotypes grown under two temperature regimes. Canadian Journal of Plant Science, 89, 961-968. http://dx.doi.org/10.4141/CJPS08188.

Hendrickson, L., Ball, M. C., Wood, J. T., Chow, W. S., \& Furbank, R. T. (2004). Low temperature effects on photosynthesis and growth of grapevine. Plant, Cell and Environment, 27, 795-809.

Jackson, D. I., \& Lombard, P. B. (1993). Environmental and management practices affecting grape composition and wine quality: a review. American Journal of Enology and Viticulture, 44, 409-430.

Kamiloglu, Ö., Polat, A. A., \& Durgaç, C. (2011). Comparison of open field and protected cultivation of five early table grape cultivars under Mediterranean conditions. Turkish Journal of Agriculture and Forestry, 35, 491-499.

Lafta, A. M., \& Lorenzen, J. H. (1995). Effect of high temperature on plant growth and carbohydrate metabolism in potato. Plant Physiology, 109, 637-643. PMid:12228617.

Lebon, E., Pellegrino, A., Tardieu, F., \& Lecoeur, J. (2004). Shoot development in grapevine (Vitis vinifera) is affected by the modular branching pattern of the stem and intra- and inter-shoot trophic competition. Annals of Botany, 93, 263-274. http://dx.doi.org/10.1093/ aob/mch038. PMid:14749253.
Mori, K., Goto-Yamamoto, N., Kitayama, M., \& Hashizume, K. (2007). Loss of anthocyanins in red-wine grape under high temperature. Journal of Experimental Botany, 58, 1935-1945. http://dx.doi. org/10.1093/jxb/erm055. PMid:17452755.

Mullins, M. G., Bouquet, A., \& Willians, L. E. (1992). Biology of the grapevine. Cambridge University Press. 239 p.

Pedro, M. J. P. Jr., Hernandes, J. L., \& Rolim, G. S. (2011). Sistema de condução em Y com e sem cobertura plástica: microclima, produção, qualidade do cacho e ocorrência de doenças fúngicas na videira 'Niagara Rosada'. Bragantia, 70, 228-233. http://dx.doi.org/10.1590/S000687052011000100030 .

Poorter, H., Niinemets, U., Poorter, L., Wright, I. J., \& Villar, R. (2009). Causes and consequences of variation in leaf mass per area (LMA): a meta-analysis. The New Phytologist, 182, 565-588. http:// dx.doi.org/10.1111/j.1469-8137.2009.02830.x. PMid:19434804.

Regina, M. A., Mota, R. V., Souza, C. R., \& Favero, A. C. (2011). Viticulture for fine wines in Brazilian Southeast. Acta Horticulturae, 910, 113-120.

Regina, M. A., Pereira, G. E., Cançado, G. M. A., \& Rodrigues, D. J. (2000). Calculate of the leaf area on grapevine through nondestructive method. Revista Brasileira de Fruticultura, 22, 310-313.

Schultz, H. (2003). Differences in hydraulic architecture account for nearisohydric and anisohydric behaviour of two field-grown Vitis vinifera L. cultivars during drought. Plant, Cell \& Environment, 26, 1393-1405. http://dx.doi.org/10.1046/j.1365-3040.2003.01064.x.

Souza, C. R., Maroco, J. P., Santos, T., Rodrigues, M. L., Lopes, C., Pereira, J. S., \& Chaves, M. M. (2003). Partial rootzone drying: regulation of stomatal aperture and carbon assimilation in field grown grapevines (Vitis vinifera). Functional Plant Biology, 30, 653-662. http://dx.doi.org/10.1071/FP02115.

Taiz, L., \& Zeiger, E. (1991). Plant physiology. Reedwood: The Benjamin/Cummings Publishing. 565 p.

Terashima, I., Hanba, Y. T., Tazoe, Y., Vyas, P., \& Yano, S. (2006). Irradiance and phenotype: comparative eco-development of sun and shade leaves in relation to photosynthetic $\mathrm{CO} 2$ diffusion. Journal of Experimental Botany, 57, 343-354. http://dx.doi.org/10.1093/jxb/ erj014. PMid:16356943.

Tonietto, J., Vianello, R. L., \& Regina, M. A. (2006). Caracterização macroclimática e potencial enológico de diferentes regióes com vocação vitícola em Minas Gerais. Informe Agropecuário, 27, 32-55.

van Leeuwen, A., Tregoat, O., Choné, X., Bois, B., Pernet, D., \& Gaudièllere, J. P. (2009). Vine water status is a key factor in grape ripening and vintage quality for red Bordeaux wine. How can it be assessed for vineyard management purposes? Journal International des Sciences de la Vigne et du Vin, 43, 121-134. 